\title{
The new Eurasia: post-Soviet space between Russia, Europe and China
}

\section{Vsevolod Samokhvalov}

To cite this article: Vsevolod Samokhvalov (2016): The new Eurasia: post-Soviet space between Russia, Europe and China, European Politics and Society, DOI: 10.1080/23745118.2016.1171285

To link to this article: http://dx.doi.org/10.1080/23745118.2016.1171285

Published online: 27 Apr 2016.

Submit your article to this journal $₫$

LIII Article views: 73

Q View related articles 드

View Crossmark data \lceil 


\title{
The new Eurasia: post-Soviet space between Russia, Europe and China
}

\author{
Vsevolod Samokhvalov \\ Department of Politics and International Studies, University of Cambridge, Cambridge, UK
}

\begin{abstract}
The research of Eurasian regionalism mostly focuses on the Eurasian core, for example, Russia, Belarus, Kazakhstan, which have been pursuing a more exclusive and closer form of integration Customs Union/Eurasian Economic Union. Other countries of the post-Soviet space are often described as post-Soviet 'escapists' or 'isolationists' and mostly discounted in the analyses of the Eurasian regionalism. The paper looks at six post-Soviet states, who opted out from the Eurasian Economic Union, and analyse their interaction with the EEU. The paper argues that despite tensions in relations with Russia, most of these countries are reluctant to entirely disrupt their economic relations with the post-Soviet Eurasia. The paper argues that six countries of the post-Soviet Eurasian periphery effectively pursue policies of a looser form association with the Eurasian core. This finding allows to argue that Eurasian regionalism, similarly to its European model, consists of the core and outer circle. The outer circle is featured by overlapping regional arrangements and growing presence of external powers and growing number of transit and trade flows linking this Eurasian periphery with the West and Asia.
\end{abstract}

\section{KEYWORDS}

Eurasia; Silk Road Economic Belt; Russia; Central Asia; Caucasus; Europe; China; Ukraine; Moldova

\section{Eurasian regional project and its periphery}

The growing importance of the vast space stretching from Central Europe to the Pacific resulted in a new strand of literature focusing on Eurasia. The signifier 'Eurasia' has originally been used to connote the entire post-Soviet space, linked to the issues of international security, inter-ethnic conflicts and geopolitics (Edwards, 2003; Smith Stegen \& Kusznir, 2015). But with the launch of the Eurasian Economic Union, its meaning was narrowed down to one specific regional organisation and its three founding members. As a result, most of works on Eurasia would either analyse institutional, legal aspects and economic of Eurasian Economic Union (Dragneva \& Wolczuk, 2013; Libman \& Vinokurov, 2012; Vinokurov \& Libman, 2012), or they would focus on the policies of and relations between Russia, Kazakhstan and Belarus (Jonson, 2004; Molchanov, 2015; Vieira, 2015). Finally, specialists in European studies have analysed Eurasian regionalism from the point of view of its interaction with the European Union (Dragneva \& Wolczuk, 2012; Popescu, 2014; Van der Togt, 2015). 
Empirically rich and insightful, these studies of Eurasia have one serious limitation. They either fully ignore significant part of the post-Soviet space, which is not part of the Eurasian Economic Union, or they reduce it to a mere object of fight of the struggle between the external actors. One of the few exceptions to be nameD is a recent work by Dutkievicz and Sakwa (2015). Even though a number of former post-Soviet states opted out from this closer form of Eurasian integration, their role and policies should not be disregarded as they constitute a significant part of this geographic space. The focus on these countries is necessary to explain what this part of the region is likely to look like.

This paper will focus on six countries in three subregions of the former Soviet territory Ukraine, Moldova in the West, Georgia and Azerbaijan in the Caucasus and Uzbekistan and Turkmenistan in Central Asia. All these countries explicitly refused to join the deeper form of post-Soviet regionalism, the Eurasian Economic Union. The first group - Georgia, Moldova and Ukraine (GMU) - is often depicted as a group of states trying to escape the Russian sphere of influence by seeking a closer association with the European Union. The second group - Azerbaijan, Turkmenistan and Uzbekistan - tends to be discarded as mostly inward looking Oriental tyrannies in pursuit of isolationist foreign policies. However, these interpretations do not entirely grasp the complexity of these countries' economic choices. The attitudes of these countries to post-Soviet regionalism vary and change over time. In the following sections, their differences and similarities will be exposed to argue that these 'Eurasian outliers' effectively pursued policies of a looser form association with Eurasian Economic Union, thus constituting a porous periphery of the Eurasian core, zone with the growing presence of global players, namely Europe and China.

\section{Not escapers, but pragmatists - GMU (Georgia, Moldova and Ukraine)}

The geo-economic choice of this group of states is often depicted in zero-sum terms. Their decision to pursue further trade relations with the European Union was often described within them as political, and even a civilisational choice between Russia and Europe (Fesenko, 2015, p. 135; White \& Feklyunina, 2014). Even though pro-European rhetoric was used by some of the governments of these countries, in reality their economic choices, especially towards Russia, remained consistent and pragmatist throughout the past 25 years. This commitment to pragmatism remained strong regardless of their officially proclaimed political choice either pro-European or pro-Russian. Despite significant fluctuations in the rhetoric of the local governments, security concerns and sometimes even dramatic deterioration of bilateral relations with Russia, these three states overall tried not to disrupt economic interaction with Russia, and did not abolish existing trade regimes.

This stability was the outcome of several counter-acting factors. On the one hand, the strong wish of some pro-European forces to pursue closer relations with the EU was stalled by Europe's inability to integrate these countries. At that time, the EU was only prepared to offer these countries quite a basic form of economic interaction: a Partnership and Cooperation Agreements (PCA) coupled with technical assistance (TACIS) and infrastructure projects (TRASECA). This lack of interest on the part of the EU drove the countries of the region to remain on the two-track in their choices of economic integration. All three countries joined the post-Soviet regional project Commonwealth of Independent 
States with its main geo-economic symbol, the CIS Free Trade Agreement, in 1994. Even though the 1994 FTA Agreement contained a number of exemptions and did not function in some cases, all three GMU countries signed a number of bilateral trade agreements and agreed to use non-conflictual means of dispute arbitration in most situations.

Any further attempts, however, undertaken by 'pro-Russian forces' to deepen postSoviet integration were blocked by internal opposition. Often, dubious background of such politicians allowed the opposition to mobilize significant popular support. In the case of Ukraine, some attempts of pro-Russian elites to proceed with deeper postSoviet integration (i.e. Single Economic Space, 1998/2003) were undermined by broader popular protests against the authoritarian president L. Kuchma. In the case of Georgia, even an allegedly corrupt and 'pro-Russian' President E. Shevardnadze made efforts to integrate the country into the system of global economic governance by joining WTO in 2000 and declined any offers to join deeper forms of post-Soviet integration, for example, the Common Economic Space in 2003. At the same time, the Georgian leader promised to look for cooperative forms of interaction with the CEP-4 and made efforts to maintain good relations with Moscow (Korrespondent.net, 2003). Moldova followed similar trajectory. Even the pro-Russian leadership led by Communist Party leader V. Voronin, after a brief rapprochement with Russia, realised that this special relationship with Moscow in fact prevented the country from receiving international aid and did not resolve economic and security issues. Given these considerations, in 2003 even the Communist Party of the Republic of Moldova effectively adhered to national common denominator: concurrent pursuit of Free Trade Area with Russia and European integration (Shapovalova, 2012, pp. 60-61).

At the same time, Eurasian pragmatists tried to avoid zero-sum logic and manage their economic interdependence by developing good bilateral relations with other countries of the Eurasian core. Moldova maintained good bilateral relations with Belarus under both pro-Russian President V. Voronin and the pro-European coalition. Relations did not change even after the EU launched its Eastern Partnership programme. Regular highlevel meetings were held and many agreements were signed, of which 64 entered into force (Froltsov, 2012, pp. 2-8). Similarly, Ukraine and Georgia maintained effective relations with Belarus and Kazakhstan. Even though the initially pro-Western Georgian President M. Saakashvili pursued a messianic vision of democratisation of the post-Soviet space, his relations with Belarus President A. Lukashenko, whom he had once called 'last dictator of Europe', eventually improved (EurasiaNet, 2007).

The tension between the Eurasian and European integration became stronger with Russia actively promoting the Eurasian Economic Union. However, the response of local elites - despite their ideological differences - was similar: a pragmatist balancing between Russia and the EU. Allegedly 'pro-Russian' Georgian leader B. Ivanishvili had strong personal animosities with the old 'pro-Western' President M. Saakashvili, but he pursued similar economic policies. Often described as 'Russia-backed oligarch', the new Georgian Prime Minister B. Ivanishvili pursued policies of deeper economic cooperation with the EU whilst at the same trying not to antagonise Russia. Within this framework, Georgia signed an Association Agreement which stipulated a Deep Comprehensive Free Trade Area (AA/DCFTA) with the EU (Ellena, 2015). Trying to reduce symbolic challenge of this move to Russia, B. Ivanishvili spoke of Georgia potential accession to the Eurasian 
Union (RFE/RL, 2013) and discussed options of deepening relations with the Eurasian Union, Russia and Belarus (Civil Georgia, 2015).

Identical policies were simultaneously pursued by 'the most pro-Russian' President of Ukraine V. Yanukovych and the 'most pro-European government' of Moldova. Both governments sought to deepen trade relations with the EU and prepared to sign an $A A$ / DCFTA. At the same time, V. Yanukovych made symmetric symbolic moves towards Russia. For example, Ukraine joined the New Free Trade Area within the Commonwealth of Independent States (CISFTA), created by eight CIS states on 18 October 2011. Similarly, to Ukraine, the pro-European government of Moldova signed an AA/DCFTA with the EU and at the same time acceded to the Free Trade Area of the CIS. The pro-European coalition in Moldova also ratified the agreement in September 2012 (Ionesii, 2013). This demonstrates that in case of the countries of shared Russian-European neighbourhood, there was no correlation between ideology and geo-economic choices of the local governments.

With the growing Russia's pressure, President V. Yanukovych tried to avoid an escalation of the conflict with Russia over Eurasian integration by depoliticising this issue. The question was referred to the respected Ukrainian businessman Petro Poroshenko, a centrist politician and at the time Minister of Foreign Trade of Ukraine. Following the trade wars between Russia and in Ukraine in early 2012, P. Poroshenko signed a Memorandum of Understanding with the main decision-making body of the post-Soviet regional project, the Eurasian Commission. The main purpose of the Memorandum was to create mechanisms which would allow the removal of tariff- and non-tariff barriers and avoid recourse to judicial mechanisms (Real Economy, 2012).

That the quest for pragmatist consensus was not disturbed even by the annexation of Crimea and the effective Russian-Ukrainian war in Donbass (Samokhvalov, 2015). Former minister of foreign trade in Yanukovych's government and centrist businessman Petro Poroshenko was elected president of Ukraine. Despite militant rhetoric from both capitals over the past two years, P. Poroshenko effectively agreed to continue trilateral negotiations to address Russia's concerns about the EU-Ukraine DCFTA. Even though, at the time of writing, the negotiations have been effectively stopped, it was formally the European Commission which made the move to halt the negotiations. The two sides were reluctant to entirely cut off economic ties, apart from the military cooperation. The trade of coal, electricity and other goods continued even though with some disruptions in informal cross-border movements on the Ukrainian/Crimean demarcation line. The fact that Poroshenko's personal business in Russia remains intact and a number of Russian businesses carry on their activities in Ukraine demonstrates that even strong military stand-off has little effect on how the counties manage their economic dependence.

Russia increasing pressure on the countries of shared neighbourhood, however, resulted in a new turn of geo-economic configuration of the region. The three countries sought to balance their dependence on trade with Russia by turning to China. Georgia most actively sought to diversify its economic relations and by 2015 had achieved a turning point in its geo-economic position when the Chinese economic presence in Georgia outweighed that of Russia (Cecire, 2015). With the launch of the Chinese regional infrastructure project for Eurasia - One Belt, One Road (OBOR) - Tbilisi did not miss the opportunity to integrate the country into that global transport infrastructure by building a new harbour on the Black Sea coast and a rail link through Georgia (Rinna, 2015). With 
the first shipment that arrived from China to Tbilisi in December 2015, the new Silk Road started its operation in East-West direction (Fokht, 2015). Trying to secure flow of freights Ukrainian government reduced the fees for transit good by the Ukrainian state railway company from Odessa to the Western borders of the country (Ukrzaliznytsia, 2016). Even though there are some serious doubts as to sustainability of this project, Georgia's turn demonstrates that the country is clearly looking for a third alternative to diversify its choices (Inozemtsev, 2015).

Similarly, the pro-Russian Ukrainian President V. Yanukovich tried to reduce Ukraine's dependency on Russian energy and markets. In particular, he also sought to deepen relations with China through three high-level visits. Ukraine agreed to lease China 160,000 hectares of arable land in the Crimea and started building a deep-water port in the peninsula which would become part of the Chinese OBOR project (Izmirli, 2014; LarouchePac, 2013; Xinhua, 2011). His successor, 'pro-Western' President Poroshenko seeks to further engage with China and deepen collaboration. The two leaders met in the framework of the Davos World Economic Forum, and investments of 15 billion Yuan were agreed. High-level commissions currently preparing top-level state visits (Gazeta-2000, 2015).

In addition, after the annexation of Crimea, Beijing tried to transfer the old Crimea contracts to Russia which now controlled the peninsula, but failed to reach an agreement (Worldcrunch, 2015). As a result, Chinese companies transferred their economic and infrastructure projects from Crimea to mainland Ukraine (Liga News, 2015). Despite all the personal conflicts between the current 'pro-Russian' Georgian leadership and the radical 'antiRussian' President Mikheil Saakashvili, who currently governs the Odessa region of Ukraine, interacted in successful delivery of the first container from the Ukrainian port Ilichevsk (near Odessa) to Kazakhstan, thus launching Great Silk Road transit in West-East direction (Xinhua, 2016). Similarly to Ukraine, Moldova also sought to intensify its relations with China both under its 'pro-Russian' President Voronin and under the pro-European coalition (Moldova.Org, 2015). Chisinau also achieved inclusion of the country in the OBOR project. In April 2015, China Shipping Group, tasked to implement the OBOR Strategy of the Chinese government, launched container shipping services through Giurgiulesti - Moldova's only port on the Danube. This contract effectively linked the Great Silk Road to the European waterway infrastructure (Lakshmi, 2015).

The above suggests that regardless of their political preferences and ideologies, a nonideological pragmatist consensus emerges among the elites of the shared Russian-European Neighbourhood. The growing presence of the European Union is obvious and might have been considered as detrimental to Russia's interests in the region. However, a significant role in this process was played by Russia, which applied security and economic leverage on these countries and pushed them to look for alternative options in their foreign economic policies. The presence of China becomes an even more important factor which will change the regional configuration from a bilateral Russian-European stand-off to a more complex and trilateral great power interaction. Since Chinese project has less of symbolic change for Russia and any conflictual strategy towards China is too risky, one can expect that Moscow will eventually choose to diffuse the tensions along the new transit route. 


\section{Isolationists or non-aligners - ATU (Azerbaijan, Turkmenistan, Uzbekistan)}

Geopolitical environment of Central Asia is different from East European periphery. There is far less of cultural affinity between these nations with Russia and far lesser interests of the EU to the region. All these created necessary cognitive landscape for a 'civilized divorce' of these counties from Russia. Russia tended to consider this part of the post-Soviet space as an underdeveloped periphery and as a source of various security challenges. Within this logic, Russia's foreign policy was driven by consideration of containment and damage control rather than a prize as it was the case with the shared Russia-EU Neighbourhood (Dmitirieva, 2014). As a result of this perception of the region, mutually beneficial security assurances became a shallow common denominator for bilateral relations between these countries and Russia.

Drawing on this consensus, the second group - the energy-rich countries of the Caucasus and Central Asia - Azerbaijan, Turkmenistan and Uzbekistan - pursued neutral and multivector foreign policies. Two of these countries, Azerbaijan and Turkmenistan, made their commitment to explicit neutrality policy or even a legal act. The concept of 'Finlandization' of Azerbaijan was used explicitly on various occasions (Valiev, 2010). Similarly, Turkmen foreign policy pursued a policy of positive neutrality by the UNSC Resolution. Uzbekistan pursued a similar ideology of self-reliance which was pervasive and penetrated all spheres of Uzbek life. However, the research of the region has shown that foreign policy labels can be imbued with different meanings and dictate various policy options. While in the dimension of foreign policy this trend has been acknowledged (Contessi, 2015), similar policy options may be traced in the foreign economic dimension of these countries.

Given the lack of mutual interest, these countries of Eurasian periphery pursued minimalist in the interaction with the Eurasian economic integration. They sought to maintain an optimal trade regime with Russia and CIS member-states, but unlike GMU-group they explicitly avoided any strong symbolic commitment to multilateral cooperation within the CIS. Azerbaijan and Turkmenistan refused to join the Free Trade Zone Agreement in 2011, whereas Uzbekistan reluctantly joined two years later. At the same time, all three counties declined the invitations to establish special relations with the Eurasian Economic Union, but also remained at the level of Partnership and Cooperation Agreement with the European Union. Turkmenistan under President S. Niazov demonstrated such a poor human rights record that EU Member States refused to ratify the generic EU-Turkmenistan Partnership and Cooperation Agreement. For the past 20 years, the two sides had to use an Interim EU-Turkmen Trade Agreement as framework for their relations.

Within this framework, Azerbaijan developed its cooperation with the EU mostly in the spheres of transport and energy transit. In particular, Baku actively worked on the EUfunded TRACECA and INOGATE transport programmes. In 1997, Azerbaijan tabled proposal for a revitalisation of the Great Silk Road. But, at the same time, it maintained close cooperation with Russia in the energy field (Iftiyev, 2010). However, Azerbaijan made it clear that any participation in deeper forms of post-Soviet integration would be unacceptable. Notably, the offer to join and, respectively polite refusal to participate in the Eurasian Economic Union was expressed by Azeri President I. Aliyev during his meeting with Kazakh President N. Nazarbayev (Izzet, 2014). At the same time, 'taking into account the potential geopolitical problems that may arise from signing the agreement with the EU, Azerbaijan 
agreed only to a limited cooperation' [with the EU]. Instead of an Association Agreement and Deep Comprehensive Free Trade Area, the EU and Azerbaijan signed only an agreement on visa facilitation at the Vilnius Summit of Eastern Partnership (Ibrahimov, 2013, p. 117). But even without Association, Agreement with the EU Azerbaijan was able to gradually increase its trade with the EU to 47.3 per cent of total foreign trade. Trade exchanges with Indonesia, Russia, Turkey and the USA follow with about a 6 per cent share each (European Commission, 2015a).

The crisis in Ukraine, falling energy prices and US rapprochement with Iran and the arrival of shale oil lost these countries wealth, which had immediate repercussions on the politics and foreign economic activity of Azerbaijan (Broers, 2015). President I. Aliev introduced a series of measures aimed at liberalising business activities and foreign trade, namely imports (Haqqin, 2015). Moreover, arrests among the top security officers accused of interference with business activities seemed to send a strong signal to the traditional Azerbaijan elites about the changing policies (RFE/RL, 2015). Russia's pressure on Azerbaijan to join the EEU raised serious security concerns and pushed Azerbiajan to seek economic alternatives. In this situation, the launch of the Chinese OBOR project became an important event echoing Azerbaijan's long-standing vision about the ancient Great Silk Road and infrastructure development. The economic perspectives of Azerbaijan were explicitly linked to closer ties with the Great Silk Road Belt (Donnan, 2015). Significant investment was made to upgrade capacities of the port of Baku on the Caspian Sea. Inaugurated personally by the Azeri President, the port became an important link between the Central Asian and the Caucasian parts of the Great Silk Road (Gasimli, 2015).

At the same time, Azerbaijan leaders openly stated their commitment to pursue closer relations with the European Union. The EU effectively removed its value-based agenda from bilateral discussions and focused on its strategic interests. In exchange, Baku expressed its commitment to support Southern Gas Corridor, which would further reduce EU dependence on Russia's energy supply. To mitigate potential risks of Russia's response to what it might see as Europe's infringement on its sphere of influence Baku increased the level of its military cooperation with Russia, a symbolically important move for Moscow (PISM, 2015). Arms trade and join military exercise have increased in 2015 demonstrating that Russia can always count on Azerbaijan's positive neutrality in the domain of international security and foreign policy. At the same time, there being not many policy-makers, Baku expect that this statement of friendliness will be reciprocated by Moscow.

Similarly, Turkmenistan, after its negative experience of energy cooperation with Russia, showed strong interest in deepening its interaction with China and later with Europe. Efforts to diversify Turkmen gas exports began in 2007-2008 with the construction of the Central Asia-China gas pipeline. Ever since Russia's imports of Turkmen gas gradually decreased from $40 \mathrm{bcm}$ (2008) to 8-10 bcm (2009-2014) per year, China had been gradually overtaking Russia as the main consumer of Turkmen gas (Gurt, 2015). This slow change was formalised with the visit of the Chinese President to Central Asia in 2013 during which Turkmenistan and China signed a Joint Declaration on Establishing the Strategic Partnership. The two leaders attended the opening ceremony of the world's second largest Galkynysh Gas Field, which highlighted the growing Chinese primacy in Turkmen gas exports. A number of high-level visits followed and 12 agreements on diplomacy, economy, energy, finance, education, culture and sub-national cooperation were signed (Ministry 
of Foreign Affairs of Chinese People's Republic, 2015). Currently, China and Turkey outweigh the Eurasian Economic Union as the destination of Turkmen exports at 74.1 per cent. In their share of Turkmen imports, Turkey, China, UAE and the USA are gradually overtaking the countries of the Eurasian Economic Union with 51 per cent versus 13.4 per cent (CIA Factbook, 2015). This data suggest that even though formally Turkmenistan pursued a policy of neutrality and isolationism, the country was gradually entering the international system of exchanges of Asian economy.

In relations with Europe, the new Turkmen President G. Berdimuhamedow promised to make some concessions in the field of human rights, which resulted in the EU governments promising to ratify the EU-Turkmen partnership and cooperation agreement (Foreign and Commonwealth Office, 2014). Soon after that the Turkmen President met the EU Commissioner for Energy S. Šefčovič on 1 May 2015. Azerbaijan, Turkey, Turkmenistan and the EU Energy Commissioner signed that day the Ashgabat Declaration expressing their intention to link the Turkmen-Azeri Trans-Caspian pipeline to the EU-sponsored Southern Gas Corridor, which would enable delivery of Turkmen gas to the EU (European Commission, 2015b). The first meeting of the Ashgabat Declaration Enlarged Working Group (EU, Azerbaijan, Turkey and Turkmenistan) at the level of deputy energy ministers took place in Brussels on 14 July 2015. Pursuing further diversification of energy exports, Turkmenistan completed a new 'East-West' pipeline due to become part of the TransCaspian-Southern Corridor link to Europe (Turkmenistan Zolotoi Vek, 2015). In addition, it has started construction of the TAPI pipelines going southwards (Turkmenistan-Afghanistan-Pakistan-India), a project supported by Western institutions (Hasanov, 2015). Furthermore, Turkmenistan actively promotes development of transport networks through the UN and other multilateral fora. In 2016 it will host the first world conference on international transport infrastructure (CaToday.Org, 2015; Ministry of Foreign Affairs of Turkmenistan, 2014). The Turkish airline Pegasus was one of the few low-cost airlines which were allowed to launch flights to Ashgabat (Trend, 2015a). All this demonstrates that despite their formal policy of neutrality, Turkmenistan and Azerbaijan were prepared to depart from the post-Soviet regional integration and get involved into the global system of economic exchanges through their Asian partners.

In case of Uzbekistan, the main motive behind its a drive to redirect its economic ties beyond the post-Soviet partner was the growing ideology of self-reliance (mustaqilik). Started as cultural renaissance and de-Russification, this doctrine resulted in situations when Uzbekistan was prepared to break its economic and production ties with Russia regardless of the risks of deindustrialisation (Teles Fazendeiro, 2015). For example, Uzbekistan did not hesitate to sacrifice deeper collaboration with Russia in aerospace industries and engage in short-term partnership with Washington even if this resulted in halting its own hi-tech industry. The primary Tashkent attitude to post-Soviet integration was to stay in as long as the commitment remained non-binding and shallow. Within this approach, Tashkent participated in a loose form of post-Soviet Eurasian Economic Community and, after careful considerations, joined the multilateral agreement on Free Trade Area with the CIS. But it was always wary of deepening integration. After signing the agreement, Uzbekistan made sure that it would not be obliged to apply national treatment to the imports from the CIS (Gadimova, 2014). Eventually, Uzbekistan did not apply any trade barriers (Garkun, 2015, p. 50), but vigorously refused to participate in deeper formats of integration such as the Customs Union and Eurasian Economic Union. Similarly, to Russia's 
wariness about the EU unilateral launch of the Eastern Partnership policy towards the countries of shared neighbourhood, Uzbekistan was not against Eurasian integration per se, but opposed the way it was presented as a far accompli or 'take it or leave package' (Interview with Uzbek Ministry of Foreign Affairs, March 2015).

Similar to other countries, Uzbekistan sought to balance its dependence on Russia by developing bilateral relations with China, Turkey and South Korea. Top-level official visits took place every year since 2004 when China allocated more than USD 1 billion in grants to the Uzbek government (Molchanov, 2015, p. 115). Official meetings of the Uzbek and Chinese Presidents in 2011, 2012 and 2014 resulted in the signing of a Declaration on Strategic Partnership, an agreement on extending gas pipelines from Uzbekistan to China and 31 more documents between Uzbekistan and China (National Information Agency of Uzbekistan, 2013). Within this logic, Uzbekistan expressed its firm intention to fully participate in and even to lead involvement of Central Asia into the Chinese Great Silk Road. The project was discussed at several meetings of an Inter-Governmental Committee launched as a part of the Chinese-Uzbek Strategic Partnership. It was also the theme of the 3rd China-Central Asia Cooperation Forum held in June 2015 in Shandong Province (Xinhua, 2015a). During the forum, several logistic centres were opened jointly by Chinese and Central Asia representatives. The meeting of the Chinese-Uzbek Inter-Governmental Committee was also held within the framework of the Forum. The two sides signed memoranda to strengthen cooperation in trade, investment, finance and communications within the Silk Road Economic Belt framework (Xinhua, 2015b, 2015c). Three pipelines were built to deliver Uzbek gas to various parts of China (Yaqing, 2015).

The presence of Chinese companies in Uzbekistan grew substantially over the past two years. Trade turnover rose from $\$ 904 \mathrm{~m}$ (2007) to $\$ 4.7 \mathrm{bn}(2014)$ (Trend, 2015b). The infrastructure projects implemented by both parties aim to give China access to South-Asia (National Information Agency of Uzbekistan, 2013). In addition, Uzbekistan seeks to involve other Asian powers in further internationalisation of their trade options. As a result, China and Turkey are gradually overtaking the Eurasian Economic Union as the main destination of Uzbek exports, at 39.9 per cent versus 29.1 per cent. An increasing role of other Asian partners confirms this trend (CIA Factbook, 2015). Similarly, the share of Uzbek imports from China, South Korea, Turkey, Germany and the USA noticeably exceeds the share of Russian and Kazakh imports (50.4 per cent versus 35.1 per cent). The fact that Tashkent and Ashgabat warmly welcomed South Korea's growing presence in infrastructure projects in the region demonstrates these countries' strategy to diversify their trade and transport orientation to a broader Eurasian space, in Eastern as well as Southern directions (Fumagalli, 2016).

Overall the countries of the ATU group pursued a more active, even though less visible, strategy of departure from the post-Soviet economic complex. While pursuing this strategy, local elites could rely on rich resource base to centralise their power and to gradually reduce their dependence on economic ties with Russia. Ideological commitment to independence or self-sufficiency were helpful to deal with the hardship of disintegrating economic ties and deindustrialisation. Reduction of the dependency on Russia was accompanied by closer economic ties with Asian players. The limitations of this model became obvious with fall of oil prices. However, Russia's growing ambitions for a deeper Eurasian integration led to politicisation of the project and further escapist policy choices pursued by these countries. This effectively resulted in further opening of 
these countries to European and - through Chinese OBOR project - Asian economic complex.

\section{Conclusions}

The case of former Soviet countries which opted out of any closer forms of post-Soviet integration shows significant changes taking place in the Eurasian space. Despite some rhetorical differences (pro-European or pro-Russian), the leaders of Georgia, Moldova and Ukraine refused to join the Eurasian Union and pursued pragmatist policies of balancing between the post-Soviet and European integration. The ideal arrangement for these countries was a Deep Comprehensive Free Trade Area with the European Union and free trade regime with the Commonwealth of Independent States. Even trade wars and the most dramatic Ukrainian crisis did not change this pragmatist approach. These countries' parallel participation in the CIS Free Trade Zone overlapping with Deep Comprehensive Free Trade Area with the EU turns them in some sort of an outer circle of Eurasian coregrey zone with overlapping arrangement and equally dense web of economic exchanges between Eurasia and Europe. However, the Ukrainian crisis pushed these countries to further look for other markets and production chains, even if at the expense of their high-tech collaboration with Russia. This led to deepening of their relations with the EU on the one hand. On the other hand, the growing presence of China allows these countries to secure alternative trade options with other Asian partners. Growing trade with the other countries of Eurasian core - Belarus and Kazakhstan - leads to further erosion of economic boundaries between Eurasian core and its periphery. Special relations and power asymmetry between Russia and China will prevent serious conflict between the two countries. However, further incorporation of these countries into China-European system of exchanges will result in further erosion of the Eurasian Economic Union as a single geoeconomic entity.

The second group of states - Azerbaijan, Turkmenistan and Uzbekistan - has been pursuing policies which led to their gradual distancing from the Eurasian core and to a deeper involvement in the global economy through trade with the Asian powers. Strong ideologies of exceptionalism and self-sufficiency were helpful to overcome this dependence even though sometimes it meant loss of high-tech industries. Sometimes, Russian foreign policy expedited this departure. The fact that Moscow treated these post-Soviet areas as underdeveloped periphery prevented serious geopolitical competition in the region. Being a source of illegal migration, Islamism threat and drug trafficking for Russia, Central Asia was not perceived as a prize to compete for. Within this thinking, Moscow did not see the EU as a potential competitor in the region and did not employ conflictual policies throughout the 1990s. This indifference had two consequences. Firstly, the countries developed deeper economic ties with Asian powers. Secondly, there was trust and proper history of relations which would be conducive to bringing these countries into Russia-led regional projects.

Uzbekistan decided not to join the Eurasian Economic Union because it saw the project as unilateral initiative adopted by Russia and promoted by Kazakhstan. Negative experience of the Russian-Turkmen energy trade prevented any meaningful dialogue in this domain. The crisis in Ukraine reassured Azerbaijan that security promises by Russia should not be taken seriously especially when it comes to a serious commitment such 
as long-term regional integration project. Russia's growing hegemony in promoting Eurasian integration led to politicisation of the project and further escapist choices pursued by these countries. The case of Azerbaijan, as well as other causes under study, demonstrates that Russia's policy of trading security in exchange for closer economic integration has reached its limits. In fact, Moscow's attempt to push this policy further became counter-productive. The crisis in Ukraine followed by the falling oil prices revealed the limitations of the oil-based development strategies and pushed these countries to liberalise and open their economies to Asian and European powers.

The above processes suggest that the Eurasian continent is being reshaped. Firstly, growing trade with Europe and China gradually 'dissolves' the purely post-Soviet element of the region. Secondly, from an entity mostly centred around Russia's vast territory, the former Soviet space gains new momentum and centres of gravity. The alternative energy infrastructure reshapes this vast geographic space into East-West direction. The growing presence of China in Georgia, Ukraine and Moldova suggest that the element of Asia has become more pronounced in the Eurasian geo-economic complex. Furthermore, the Chinese OBOR project creates new transport infrastructure redirecting transit routes from Northern Eurasia southwards to Central Asia, Caucasus, Turkey and then to Southern and Eastern Europe. Also, new southward transit routes from Central Asia to South Asia and Gulf states also add new geographic spin to this region. This new regionalism challenges the frequent assumption that genuine regionalism is possible only between countries with a similar ideology. In the Eurasian peripheral project, countries of pro-democratic polities (GMU) have close interaction with soft and tough authoritarian (ATU) and communist system (China).

Despite all formal declaration about Russian-Chinese cooperation, there is obvious tension between the core of Eurasian regional project and its periphery. In fact, if the China-driven integration momentum is maintained and spread further, then Eurasian periphery will turn into a central axis of a new megaregional entity of the size of continent stretching from China to Europe. The future of this new continentalism will, however, still depend on the relations between Russia and China. If their relations develop within the same cooperative paradigm, the two projects will coexist and concurrent process of growing dissolution of the post-Soviet Eurasian core in broader China-Europe system of exchanges. If Russian-Chinese relations deteriorate, then it is likely that Russia will employ conflictual policies towards the countries of Eurasian periphery to increase the costs of their rapprochement with China. This will then result in destabilisation and series of crises in these countries with potential spill-over effects in broader Central Asian, Caucasus and shared neighbourhood.

\section{References}

Broers, L. (2015, October 29). Parliamentary election highlights Azerbaijan's change dilemma. Chatham House Policy Brief. Retrieved December 2, 2015, from https://www.chathamhouse.org/ expert/comment/parliamentary-election-highlights-azerbaijan-s-change-dilemma\#sthash. HB3P8DWr.dpuf

CATODAY.ORG. (2015, December 30). Ashgabat mozhet stati krupneishim mezhdunarodno-tranzitym tsenrom. Retrieved January 1, 2016, from http://catoday.org/centrasia/24067-ashhabad-mozhetstat-krupneyshim-mezhdunarodnym-transportno-tranzitnym-centrom.html 
Cecire, M. T. (2015, May 2). China's growing presence in Georgia. The Diplomat. Retrieved January 6, 2016, from http://thediplomat.com/2015/05/chinas-growing-presence-in-georgia/

CIA FACTBOOK. (2015). Turkmenistan export and import partners. Retrieved January 1, 2016, from https://www.cia.gov/library/publications/the-world-factbook/fields/2050.html\#tx

Civil Georgia. (2015, April 23). Belarus, Georgia pledge to Deepen Ties. Retrieved December 12, 2015, from http://www.civil.ge/eng/article.php?id=28213

Contessi, N. P. (2015). Foreign and security policy diversification in Eurasia: Issue splitting, co-alignment, and relational power. Problems of Post-Communism, 62(5), 299-311.

Dmitirieva, M. O. (2014). Evolutsia vnsehnie politiki v Tsentralnoi Azii. Diskussiya, 2(43), February.

Donnan, S. (2015, 12 March). Azerbaijan's economic promise is tied to Silk Road. Financial Times. Retrieved December 2, 2015, from http://www.ft.com/cms/s/0/b72375ee-be99-11e4-803600144feab7de.html\#axzz3tBtbPtKu/

Dragneva, R., \& Wolczuk, K. (2012, August 6). Russia, the Eurasian Customs Union and the EU: Cooperation, stagnation or rivalry? Chatham House Briefing Paper, REP BP 2012/01.

Dragneva, R., \& Wolczuk, K. (2013). Eurasian economic integration: Law, policy and politics. London: Elgar.

Dutkievicz, P., \& Sakwa, R. (2015). Eurasian integration view from within. London: Routledge.

Edwards, M. (2003). The new great game and the new great gamers: Disciples of Kipling and Mackinder. Central Asian Survey, 22(1), 83-102. doi:10.1080/026349303200010864

Ellena, M. (2015, June 26). Georgia's EU trade deal: More pain than gain? Retrieved January 6, 2016, from http://www.eurasianet.org/node/74041

EurasiaNet. (2007, April 7). Odd bedfellows? Georgia, Belarus explore partnership. Retrieved January 5, 2016, from http://www.eurasianet.org/departments/insight/articles/100307a.shtml

European Commission. (2015a, October 20). Azerbaijan, trade with world. Directorate-General for trade, Brussels. Retrieved January 2, 2016, from http://trade.ec.europa.eu/doclib/docs/2006/ september/tradoc_113347.pdf

European Commission. (2015b, May 1). Ashgabat declaration. Retrieved December 30, 2015, from https://ec.europa.eu/commission/2014-2019/sefcovic/announcements/ashgabat-declaration_en

Fesenko, V. (2015). Ukraine: Between Europe and Eurasia. In P. Dutkievicz \& R. Sakwa (Eds.), Eurasian integration view from within (pp. 126-150). London: Routledge.

Fokht, E. (2015, December 13). Pervypoezdpovelikomu 'Shelkovomuputi' v obkhodRossoiipribyl v Gruziu. RBC.ru. Retrieved December 18, 2015, from http://www.rbc.ru/business/13/12/2015/ 566d50109a79472274a8feec?from=main

Foreign and Commonwealth Office. (2014). EU-Turkmenistan relations. Documents considered by the Committee on 17 December 2014, European Scrutiny Committee, London. Retrieved December 31, 2015, from http://www.publications.parliament.uk/pa/cm201415/cmselect/cmeuleg/219xxvi/21908.html

Froltsov, V. V. (2012). Belarus: A pragmatic approach toward Moldova. In M. Kisienkowski \& W. Schreiber (Eds.), Moldova: Arena of international influences (22-44). Plymouth: Lexington Books.

Fumagalli, M. (2016). Growing inter-Asian connections: Links, rivalries, and challenges in South KoreanCentral Asian relations. Journal of Eurasian Studies, 7(1), 39-48. doi:10.1016/j.euras.2015.10.004

Gadimova, N. (2014, April 3). Uzbekistan joins CIS free trade zone. AzerNews. Retrieved November 23, 2015, from http://www.azernews.az/region/65752.html

Garkun, G. V. (2015). Razvitie i Deatelnosti Sodruzhestva Nezavisimyh Gosudarstv v 2014-m godu. Sbornik Analiticheskih Materialov, Vypusk 3. Minsk: Ispolnitelny Komitet Sodruzhestva Nezavisimyh Gosudarstv, Informatsionno-Analiticheskiy Departament.

Gasimli, V. (2015, 2 October). The new Baku international seaport: A nexus for the New Silk Road. Eurasia Daily Monitor, 12(178). Retrieved December 2, 2015, from http://www.jamestown.org/ programs/edm/single/?tx_ttnews[tt_news=44442\&cHash=7239541e890627e857bebc29ff6186eb\#. Vl89YysXuBp]

Gazeta-2000. (2015, December 1). Posol Ukrainy v KNR Oleg Demin o visite Poroshenko v Kitai, sintezgaze I vizovoi gluposti. Retrieved December 21, 2015, from http://www.2000.ua/spectemy/2000-vkitae/demin.htm 
Gurt, M. (2015, July 8). Turkmenistan says Russia's Gazprom has not paid for any gas this year. Reuters. Retrieved January 1, 2016, from http://uk.reuters.com/article/gas-turkmenistan-gazpromidUKL8N0ZO30Q20150708

Haqqin, A. Z. (2015, December 30). Ilham Aliev I likvidirovalmonopoliuna import. Retrieved January 6, 2015, from http://haqqin.az/news/60358

Hasanov, H. (2015, December 23). Energy charter supports TAPI project. Trend. Retrieved January 1, 2016, from http://en.trend.az/business/economy/2471960.html

Ibrahimov, R. (2013). EU external policies towards the counties of south Caucasus: How far it is from realization. Baku: CAM.

Iftiyev, E. (2010, April 11). Gazprom-SOCAR gas deal: Should Azerbaijan commit to a long-term contract? Today's Zaman. Retrieved September 2, 2015, from http://www.todayszaman.com/ business_gazprom-socar-gas-deal-should-azerbaijan-commit-to-a-long-term-contract_207061. html

Inozemtsev, V. (2015, December 17). From China to Europe without Russia? Intersections. Retrieved December, 18, 2012, from http://intersectionproject.eu/article/economy/china-europe-withoutrussia\#sthash.mrid3ulF.dpuf

Ionesii, I. (2013, January 16). Zona de comerț liber CIS - un accord modernizat. Radio Europa Libera. Retrieved January 5, 2016, from http://www.europalibera.org/content/article/24825216.html

Ismayilov, K., \& Zesztow, K. (2015). Azerbaijan's risky game: Between Russia and the West. PISM Policy Papers, 32 (134), October 2015.

Izmirli, I. (2014, February 6). Sale of Crimean Land by Yanukovych: 'Made in/for China'. Eurasia Daily Monitor, 11(24). Retrieved December 18, 2015, from http://www.jamestown.org/single/?tx_ttnews [tt_news] $=41930 \&$ no_cache $=1 \# . V n Q 2 f y s X v A E$

Izzet, I. (2014, June 11). Azerbaijan yet has no intentions to join Eurasian Union. Trend. Retrieved September 2, 2015, from http://en.trend.az/azerbaijan/politics/2284020.html

Jonson, L. (2004). Vladimir Putin and Central Asia: The shaping of Russian foreign policy. New York, NY: Tauris.

Korrespondent.Net. (2003, February 24). Edinoevekonomicheskoevprostranstvo: reaktsia stran-sosedei. Retrieved December 30, 2015, from http://korrespondent.net/business/65727-edinoeekonomicheskoe-prostranstvo-reakciya-stran-sosedej

Lakshmi, A. (2015, June 27). China shipping service to Moldova. Maritime Professionals. Retrieved December 30, 2015, from http://www.maritimeprofessional.com/news/china-shipping-servicemoldova-273650

LarouchePac. (2013, December 6). Yanukovych in China signs agreements, invites Xi to Kiev, supports 'Silk Road'. Retrieved December 18, 2015, from http://archive.larouchepac.com/node/29109

Libman, A., \& Vinokurov, E. (2012). Holding-together regionalism. Basingstoke: Palgrave Macmillan.

Liga News. (2015, January 21). Poroshenko priglasil premier-minister ipredsedatelia KNR posetitiUkrainu. Retrieved December 21, 2015, from http://censor.net.ua/photo_news/320992/poroshenko_ priglasil_premerministra_i_predsedatelya_knr_posetit_ukrainu_foto

Ministry of Foreign Affairs of Chinese People's Republic. (2015). China and Turkmenistan. Retrieved January 1, 2016, from http://www.fmprc.gov.cn/mfa_eng/wjb_663304/zzjg_663340/dozys_ 664276/gjlb_664280/3245_664372/

Ministry of Foreign Affairs of Turkmenistan. (2014, September 4). Ashgabat declaration on the role of transport and transit corridors in ensuring international cooperation, stability and sustainable development. Retrieved January 1, 2016, from http://www.mfa.gov.tm/en/news-en/1962-ashgabatdeclaration-on-the-role-of-transport-and-transit-corridors-in-ensuring-international-cooperationstability-and-sustainable-development

Molchanov, M. (2015). Eurasian regionalisms and Russian foreign policy. Aldershot: Ashgate.

Moldova.org. (2015, March 12). Republica Moldova îșiintensificărelațiileeconomice cu China. Retrieved December 21, 2015, from http://www.moldova.org/republica-moldova-isi-intensifica-relatiileeconomice-cu-china/

National Information Agency of Uzbekistan. (2013, September 9). Uzbekistan i Kitai: Novye Gorizonty strategicheskogo partnerstva. Retrieved December 2, 2015, from http://uza.uz/ru/politics/ uzbekistan-kitai-novye-gorizonty-strategicheskogo-partnerstva-09.09.2013-25180 
Popescu, N. (2014, September 9). Eurasian Union: The real, the imaginary and the likely. EU ISS Chaillot Paper, 132.

Real Economy. (2012, July 27). Ukrainapidpysala Memorandum pro spivpratsiu z EvraziyskoyuKomissieyu. Retrieved August 22, 2015, from http://real-economy.com.ua/news/ 21698.html

RFE/RL. (2013, September 9). Interview: Georgian PM still aiming for EU, but doesn't rule out Eurasian Union. Retrieved January 6, 2016, from http://www.rferl.org/content/georgia-ivanishvili-interview/ 25100642.html

RFE/RL. (2015, December 2). Azerbaijan arrests seven security officials. Retrieved December 2, 2015, from http://www.rferl.org/content/azerbaijan-arrests-seven-security-officials/27316464.html

Rinna, T. (2015, December 3). The South Caucasus and China's rising presence. New Eastern Europe. Retrieved January 6, 2015, from http://neweasterneurope.eu/articles-and-commentary/1811-thesouth-caucasus-and-china-s-rising-presence

Samokhvalov, V. (2015). Ukraine between Russia and the European Union: Triangle revisited. EuropeAsia Studies, 67(9), 1371-1393.

Shapovalova, N. (2012). The European Union: A privileged partnership with Moldova. In M. Kisienkowski \& W. Schreiber (Eds.), Moldova: Arena of international influences (pp. 51-77). Plymouth: Lexington Books.

Smith Stegen, K., \& Kusznir, J. (2015). Outcomes and strategies in the 'new great game': China and the Caspian states emerge as winners. Journal of Eurasian Studies, 6, 91-106.

Teles Fazendeiro, B. (2015). Uzbekistan's 'spirit' of self-reliance and the logic of appropriateness: TAPOich and interaction with Russia. Central Asian Survey, 34(4), 484-498.

Trend. (2015a, December 1). Turkish low-cost airline to start flights to Turkmenistan. Retrieved December 2, 2015, from http://en.trend.az/business/economy/2463419.html

Trend. (2015b, September 3). China, Uzbekistan hail strategic partnership, eye co-op boost. Retrieved December 2, 2015, from http://en.trend.az/casia/uzbekistan/2429435.html

Turkmenistan Zolotoi Vek. (2015, December 25). Gazoprovod 'Vostok-Zapad' otkryvaet novye vozmozhnosti diversifikaciii eksporta uglevodorodov. Retrieved January 1, 2016, from http://www. turkmenistan.gov.tm/?id=10163

Ukrzaliznytsia. (2016, January 29). Ukrzaliznytsia lowers tariff for Transit of containers from Illichivsk to EU By 60\%. Retrieved March 10, 2016, from http://en.cfts.org.ua/news/ukrzaliznytsia_lowers_tariff_ for_transit_of_containers_from_illichivsk_to_eu_by_60

Valiev, A. (2010). Finlandization or strategy of keeping the balance? Azerbaijan foreign policy since the Russia-Georgia war. PONARS Eurasia Policy Memo No. 112. Retrieved December 31, 2015, from https://www.gwu.edu/ ieresgwu/assets/docs/pepm_112.pdf

Van der Togt, T. (2015, November 23). From competition to compatibility: Striking a Eurasian balance. Netherlands Institute of International Relations Clingendael: The Hague. Retrieved January 11, 2016, from http://www.clingendael.nl/sites/default/files/Eurasian_Union_Report_FINAL.pdf

Vieira, A. (2015). Eurasian integration: Elite perspectives before and after the Ukraine crisis. Post-Soviet Affairs. doi:10.1080/1060586X.2015.1118200

Vinokurov, E., \& Libman, A. (2012). Eurasian integration: Challenges of transcontinental regionalism. Basingstoke: Palgrave Macmillan.

White, S., \& Feklyunina, V. (2014). Identity and foreign policy in Russia, Ukraine and Belarus. Basingstoke: Palgrave Macmillan.

Worldcrunch. (2015, May 6). Popov E., Skorobagatko D., Chinese investment in Crimea is 'political' backing for Russia. Retrieved January 6, 2016, from http://www.worldcrunch.com/world-affairs/ chinese-investment-in-crimea-is-political-backing-for-russia/c1s15851/

Xinhua. (2011, June 18). Chinese president kicks off state visit to Ukraine. Retrieved December 18, 2015, from http://news.xinhuanet.com/english2010/china/2011-06/18/c_13937149.htm

Xinhua. (2015a, 16 June). China, Central Asia seek cooperation on Silk Road economic belt. Xinhua. Retrieved November 27, 2015, from http://news.xinhuanet.com/english/2015-06/16/c 134331124_2.htm 
Xinhua. (2015b). China, Uzbekistan to strengthen cooperation under the Silk Road initiative. 15. Retrieved November 26, 2015, from http://news.xinhuanet.com/english/2015-06/15/c_134328727. htm

Xinhua. (2015c, June 17). China, Uzbekistan sign protocol for closer trade ties. Xinhua. Retrieved November 28, 2015, from http://news.xinhuanet.com/english/2015-06/17/c_134334771.htm

Xinhua. (2016, January 26). First container train from Ukraine to China passes through Azerbaijan. Retrieved March 10, 2016, from http://news.xinhuanet.com/english/2016-01/24/c_135039015.htm Yaqing, D. (2015, July 29). Advancing towards the West. Beijing Review. Retrieved November 27, 2015, from http://www.bjreview.com/Business/201509/t20150909_800037814.html 